\title{
The Right to be Present as a Guarantee of Justice in Procedure
}

\author{
ATTILA MENYHÁRD
}

\begin{abstract}
The right to be present is to be assessed in context of oral procedure and the function of procedure, i.e. if procedure shall aim at promoting social justice. The right to be present is not an absolute right of the party. It may be limited by the procedural rights of the other party but the grounds for such limitation are to be construed very narrowly. The right to be present is mostly understood as implied in the right to fair trial. It is argued that the right to be present is an element of the guarantees of justice and trust in the procedure. The right to be present is less protected in civil procedures, although justice and trust are important policy in civil actions as well.
\end{abstract}

Keywords: $\bullet$ civil actions $\bullet$ justice $・$ limits on right to presence $\bullet$ oral procedure $\bullet$ right to be present $\bullet$ right to fair trial

CoRRESPONDENCE AdDRESS: Attila Menyhárd, Ph.D., Professor, Eötvös Loránd University, Faculty of Law, Department of Administrative Law,H-1053 Budapest, Egyetem tér 1-3, Hungary, email: attila.neyhard@ajk.elte.hu.

https://doi.org/10.4335/978-961-6842-96-9.51-57

ISBN 978-961-6842-96-9 (pdf)

(C) 2020 Institute for Local Self-Government Maribor

Available online at http://www.lex-localis.press. 


\section{The social function of the right to be present}

Legal relationships are social relationships. Although the importance and the consequences of this statement have been emphasized and elaborated primarily for contractual relationships (Kohler, Josef 1921: 51, MacNeil, Ian, 1974: 715), I believe that it is a general truth that holds for all kinds of legal relationships. This comes from the nature of the law, because law is designed for organizing social relationships. Thus, procedural laws are to be assessed as social relationships as well. In order to understand the importance of the right to be present in a procedure, be it a criminal or a civil one, one should consider the messages of the well-known novel of Franz Kafka, "The Trial." Josef $\mathrm{K}$., the citizen is the subject to a procedure which is for him completely unknowable and unpredictable. The trial is for him a labyrinth and the distance between him and the power taking action against him and providing justice is extremely big (Posner, Richard, 1998: 135.). Why the procedure against the average citizen, Josef $\mathrm{K}$ was so suggestive in demonstrating the depressing and devastating feeling of separation? Because Josef $\mathrm{K}$ did not get the chance of taking part in the procedure. The distance between the state and the citizen is so big that the authorities appear for him as pure manifestation of power, not more. This result may comply with the view of autocratic regimes but certainly is incompatible with the idea of the modern welfare state or with the view that the state is a social consent and it is to serve the society.

That is, the right to be present is not simply one of the values for the common good but is to be seen as an important element of the social function of the state and of the procedure. The relationship of the state and the citizen seeking justice or suffering a punishment as a consequence of violating the basic values of the social community is one of the most important factors of the society. Law is the tool of exercising the public power, which is to provide justice with establishing rights and obligations in the social relationships as well as in the procedures. It seems to be an emerging tendency in our modern societies that the quest for justice becomes less important as a result of expanding formalism, judicial organisation and judicial attitude. The priority of closing down social conflicts as quickly as possible makes enforcement of law self-serving and increases its distance from social reality. The growing gap between the social reality and the judicial system, that is, between the state and the citizen results in tension which may, in extreme situations, even undermine the power of the state. We expect the state providing justice on the basis of truth. This fundamental function of the state is threatened if persons, whose position is affected by the finding of the court or the authority are not the part of the procedure.

\section{$2 \quad$ Presence as a right}

Right of presence is basically assessed as an element of the right to fair trial, which is a protected human right and normally held as a principle provided in our constitutions as well. This approach, however, has certain implications which may call for revisiting this idea. The right to fair trial is a mutual right of the parties and shall be seen as provided to 
them on an equal footing. From this follows that the right to fair trial of the party may be a limit on the procedural right of the other party. That is, if the right to be present is assumed as an element of the right to fair trial, it may (and even shall) be limited in order to guarantee the right to fair trial of the other party. An understanding of the right to fair trial may be as a right of the citizen vis-á-vis the state to have social justice provided. That is, fair trial and procedural justice are interrelated, conceptually and practically as well. Procedural justice, as well as the right to presence do not have a value for their own sake, but they are to serve material or substantive justice which should be the main goal of the legal system as a whole. From this angle, the right of presence is a guarantee of justice in civil and in criminal procedure as well.

It became a real issue in the state procedural laws in the USA if the plaintiff, especially if she is a minor or is the alleged victim of medical malpractice case, due to her age, her incapacity to communicate or to understand what is happening in the courtroom (often caused by the defendant's alleged wrongdoing) may or even should be rejected to be present in the jury trial, completely or at least in the liability phase. In cases of serious personal injury cases the presence of the plaintiff could influence the jury due to her pitiful status and appearance in a way which deprived the jury of the opportunity of assessing of the defendant's conduct objectively. The Georgia Supreme Court (Kesterson v Jarrett) and also the Indiana Supreme Court (Jordan ex rel. Jordan v Deery) decided that the plaintiff can never be excluded from the courtroom because of a risk of prejudice that may result. Although this conclusion has not been questioned, the judgements have been criticized on the ground that the legal justification might not been correct. It has been suggested that the plaintiff's right to be present should be acknowledged as an independent right instead of assuming it as implied in the right to fair trial (Farber, Joanna: 2014, 724, 726 and Olearchik, Meredith Quinn: 2004, 1530). Similar critic has been expressed concerning the right to be present of minors (Lundergan, E Kirsten: 1987, 187). One of the possible solutions could be identifying the "right to be heard" as an independent right within the due process clause and certainly not to be left upon the discretion of the judge (Grunes, Allen P: 1987, 407).

The right to be present is not an absolute right. The absence of the party cannot be an obstacle to the procedure. If absence could be a barrier to the action, it would obviously violate the other party's interests and the other party's right to fair trial. That is, the party to a civil action may waive its right to be present simply by being absent or the party can be deprived the opportunity to be present due to his or her conduct violating the rules and principles of the trial. The right to be present is to be contrasted to the other party's procedural rights, especially the other party's right to fair trial. This may result in imposing limits on the right to be present. Such limitation, however, does not seem to be justifiable by the age, health conditions, personal injury or other personal circumstances by the party.

The right to be present is not simply about allowing the party, the accused or the victim to acquire direct impressions from the procedure and to control the procedure in a way, 
but is to put into the context of the goal and function of the procedure and contrasted to the paradigm of written or oral nature of the procedure. Our procedural laws, either civil or criminal, are a kind of mixture of oral and written procedure. Presence, and right of presence in the procedure is tightly linked to the oral procedure. In written procedure there is no sense to speak about presence. Oral procedure is not a value for itself either, but it is an important element of convincing the court about material or substantive justice and, on the other hand, providing the opportunity and, at the same time, the obligation to the judge to establish his or her personal conviction of the case. With other words, oral procedure connects the judge with the reality, which is the key for enforcing justice in the society. This is, after all, the primary goal of court procedures.

\section{$3 \quad$ Expanding formalism: criminal vs civil actions}

Changes of our procedural laws and the judicial organisation in the past decades present a tendency of expanding formalism: the priority of the written form of contact, the decreasing role of direct communication between the court and the citizen, the growing role of legal representatives (lawyers) in the procedure degrade justice to a service provided by the state to the citizen, that is, a product sold to the society. The consequence is the broadening gap between the exercising of statutory power and the citizen seeking justice. Such developments are detrimental to the society, because the loss of the faith in justice alienates the citizens from the state and removes law from social justice. If this occurs, the law becomes the limit of seeking social justice instead of promoting it.

Criminal procedure is about exercising the power of the state against the citizen. Thus, it reflects the relationship of the state and the citizen. It is the manifestation of power of the community vis-á-vis the person accused with an offence against the community. Such relationship, contrasted to civil law relationships, cannot be privy to the parties. If procedural justice is assumed as equal positions provided to the parties, the control of the community over public offences would be limited, which is not the socially desirable result. That is a point which makes a basic difference in the paradigm of criminal procedure on the one hand and the paradigm of civil procedure on the other hand. The position of the public prosecutor representing the social community in a criminal procedure vis-á-vis the accused is not the same as the position of the plaintiff to the defendant in a civil litigation and this holds for the accused and the defendant respectively. The civil procedure reflects the relationship of the citizen to citizen. It holds to civil procedure as well that, in absence of fair trial, promoting justice would only be incidental and the rule of law could not prevail. That is, the risk of arbitrary judgements of courts could not be reduced and the reciprocity of the citizen's relationship to the state could not be guaranteed.

\section{$4 \quad$ Right to be present as a Human Right}

From the point of view of protection of Human Rights, right of presence is an element of the right to fair trial in context of criminal as well as of civil procedure (Leanza, Piero, 
2014, 10). As it has been established by the ECHR in the case of Hermi v Italy (2006, $\mathrm{GC}$ ), the right of presence is a precondition of exercising those rights that are provided as guarantees in Art 6 (1) and (3) of the European Convention of Human Rights. As Piero Leanza stressed it, although the right of presence is generally accepted as being of universal application in criminal trials, and the absence of the party can only be justified in exceptional cases and under certain exceptional circumstances, the presence of the party to a civil procedure is considered to be necessary only in exceptional cases. In context of civil procedure, right of presence is seen as a consequence of the right of equality of arms. In Pashayev v Azerbaijan the Court established that "Article 6 of the Convention does not guarantee the right to attend a civil court in person, but rather a more general right to present one's case effectively before a court and to enjoy equality of arms with the opposing side." Thus, it is not a right guaranteed per se by Article 6 of the Convention. In the majority of cases the presence of the legal representative is sufficient in order to comply with the requirements of the Convention in this respect.

Considering the consequences of this approach we might conclude that, contrasted to criminal procedure, the right of presence has only a secondary importance in civil procedures. International tendencies in legislation and court practice in regulating civil procedure may confirm this approach. It seems to be a dominating view that, in civil procedure, written communication between the parties and with the court is sufficient and the oral nature of the procedure is diminishing. This approach, however, involves considerable risks and implications that are hardly to accept. One of these implications is that, as the right of presence is an element of the right to fair trial, and the right to fair trial is an element of providing justice to the citizen, in civil law cases promoting justice would be less important than in criminal ones. Considering the function of the state and the law in the society, I don't think that such a conclusion could be properly justified. Another implication is that as oral procedure connects the judge with reality, abandoning oral elements results in that reality is less important in a civil procedure than in a criminal one. This is the approach degrading justice to a kind of public service provided by the state to the citizen, not more. This would mean that in context of civil law, the state waives the goal of promoting justice. I don't think that such conclusion could be justified convincingly either. A further implication is that with emphasizing the importance of written procedure and the priority of procedural justice as contrasted to substantive justice, formalities play a central role in the procedure. Such formalities, however, do not have a value in itself. Overestimating their role is a great danger for promoting social justice in civil law cases.

\section{The civil procedure: A Hungarian example}

More than hundred years ago, in 1911, Sándor Plósz, the "father" of the first modern civil procedure in Hungary, commented the civil procedural rules drafted under his leadership and supervision with the following words: "in the ordinary proceedings, as the consequence of written procedure, formalities prevail. This, however, becomes often fatal to the enforcement of substantive justice, because it limits the free activity of the judge in 
revealing the facts of the case properly and punishes even the minor negligence of the party with harsh consequences which is detrimental to finding and providing justice. Moreover, it makes even the simplest cases difficult and long lasting." (Explanatory notes to the Bill of the Civil Procedure 1911).

The new Hungarian Civil Procedure Act enacted in 2016 (Act no. CXXX on Civil Procedure) emphasizes that it attempts to provide procedural justice instead of substantive one and shifts to the importance of formalities. I am afraid, that this trend is not a Hungarian speciality. I believe, that giving up the quest for substantive justice undermines the public trust vested into the state and into the law, which results in social disfunction because the law and justice would not be enforced. Just coming back to our example of the case of Josef $\mathrm{K}$ in "The Trial" of Franz Kafka, from the point of view of the citizen it does not really matter if the procedure was a criminal or a civil one. It also could have been a claim for damages or a case of inheritance, like it was the case in the roman of Charles Dickens with the title "Bleakhouse." We should not accept that substantive justice is less important in civil law cases than in criminal ones, otherwise we build a distance between the citizen as a human being and the society. This also endangers the trust in the law among the members of the society. That is, as a final conclusion, I would suggest revisiting our prevailing view about the role and importance of the right of presence in civil procedure.

I believe, that in order to establish the role of the right to be present in the civil procedure one has to consider first the importance of oral procedure. Today, this does not seem to be the mainstream view. Results of the technological developments would suggest that the modern ways of electronic communication, the possibility of online dispute resolution in particular may make the personal interaction of the court and parties unnecessary. The history of civil procedures presents that the tendency of unpersonal written communication always shift the procedure to formalities. Formalities never promote justice and increase the distance between the citizen and the state. As a result, the gap between the state and the citizen undermines trust in the judiciary and, on a longer run, in the law. This result is socially not desirable.

\section{Conclusions}

The right to be present in the procedure is less protected in civil actions compared to criminal procedure. The lower level of protection may be justified by the nature of private law relationships and by the nature of the civil procedure, i.e. the equal position of the parties. Due to the mutual rights of the parties, the procedural rights of the other party, the other party's right to fair trial, in particular, may limit the right to be present of the party. Such limitations are not to be justified by the party's personal qualities or personal conditions. The party, however, may waive its right to be present. The right to be present is to be assessed in context of oral procedure which is a guarantee of promoting justice in civil actions. If the procedure law does not aim at promoting justice, the growing gap 
between the state and citizen undermines the trust in the judiciary, the state and the law. This is the factor underlying the importance and the value of the right to be present.

\section{References:}

Farber, J. (2014) State Constitutional Law - Due Process - Georgia Supreme Court Grants Injured Civil Litigants the Right to Be Present in Court Regardless of Mental Capacity. Kesterson v. Jarrett, 728 S.E. 2D 557 (GA. 2012), Rutgers Law Journal, 44(4), pp. 709 - 726.

Grunes, A. P. (1987) Exclusion of Plaintiffs from the Courtroom in Personal Injury Actions: A Matter of Discretion or Constitutional Right, Case Western Reserve Law Review, 38(3), pp. 387-407.

Kohler, J. (1921) Philosophy of Law (New York: The Macmillan Company).

Lundergan, E. K. (1987) The Right to Be Present: Should It Apply to the Involuntary Civil Commitment Hearing, New Mexico Law Review, 17(1), pp. 165 - 188.

Leanza, P. (2014) Piero Leanza and Ondrej Pridal, The Right to a Fair Trial. Article 6 of the European Convention on Human Rights, Kluwer Law International, 2014. Reprinted from the book, Chapter 3, with permission of Kluwer Law International.

(http://www.ejtn.eu/PageFiles/15659/Selected\%20Aspects\%20of\%20the\%20Right $\% 20$ to $\% 20 a \%$ 20Fair\%20Trial.pdf)

Macneil, I. R (1974) The Many Futures of Contract, Southern California Law Review, 47, p. 691.

Olearchik, M. Q. (2004) State Constitutional Right to Civil Trial by Jury in Indiana includes the Right to Be Present in the Courtroom. Rutgers Law Journal, 35(4), pp. 1517 - 1530.

Posner, R. (1998) Law and Literature (Cambridge: Harvard University Press).

Hermi v Italy, Judgment, App No 18114/02, [2006] ECHR 875.

Pashayev v Aserbaijan, App No 36084/06, Judgement of 28 February 2012.

Jordan v Deery, 778 N.E.2d 1264 (Ind 2002).

Kesterson v. Jarrett, 704 S.E. 2d 878, 880 (Ga. Ct. App. 2010). 